\title{
FROM THE BIG MAC AND IKEA SOCIETY TO THE ENVIRONMENTAL AESTHETICS, SMART CITIES AND STORYTELLING ARCHITECTURE
}

Irena Kuletin Ćulafić

University of Belgrade - Faculty of Architecture

kuletin@arh.bg.ac.rs
A B S T R A C T

Our global society is encountering different challenges of the twentyfirst century. Our cities are in the process of constant transformation influenced by urbanisation, globalisation, advanced technologies, environmental and ecological changes, social, political and economic crises. While corporative capitalism has flourished, world population is growing and our cities are sprawling, architecture is reaching almost utopian visions and the boundaries of aesthetics are becoming more and more loose and permeable. Today our contemporary society lives and acts aesthetically. From art, architecture, music, religion, politics, communication, technological gadgets, homes, gardens, clothes, cuisine to sport and life coaching, everything is a subject to aesthetical consideration.

Aesthetical consideration of architecture and urbanism in a constantly changing world demands critical and interactive approaches, that will not only deal with theoretical aesthetic opinions, but also the practical ones. Accordingly, this paper seeks to discuss aesthetical problems of contemporary architecture and urban planning from global, environmental, technological and social points of view.

Nature is no longer seen as a paradigmatic object of aesthetic experience, but as our unique collective environment upon which we humans depend. Therefore architecture emerges etic and aesthetic approaches in order to reconsider burden of our cities and possible ways of their future development. 


\section{INTRODUCTION}

Almost two centuries ago, a famous Danish philosopher and the progenitor of contemporary existentialism, Søren Kierkegaard, argued that the aesthetic stage of man's development should be exceeded by the ethical, and then the religious. ${ }^{1}$ Nowadays Kierkegaard's idea has been turned upside down. The aesthetic has become the highest principle of life and the essential place of human emancipation in society. By problematising the boundaries of philosophical and artistic thinking, aesthetics has expanded to almost all aspects of human life in modern global society. While the aesthetic field of art has reached the level of amateurism, architecture retains the integrity of the aesthetic based primarily on advanced technologies and the progressive improvement of new techniques in the design and construction of architectural projects. Current architectural trends such as: intelligent architecture, smart cities, experimental architectural practices, digital architecture, architecture of exuberance, global architecture and planning, etc., are based on their aesthetic and technical achievements in various BIM (Building Information Modeling) softwares, robotics, artificial intelligence and nanotechnologies. New materials and increasingly perfect building techniques support the most extreme architectural ideas. Therefore, one of the main goals of architecture in its aesthetic domain today is to make special experiences of architectural buildings and spaces. This specific aesthetic, political, economic and cultural necessity of architecture for attractiveness, establishes its ethical antithesis in the form of environmentalism, ecology, sustainable development, requirements for the protection and preservation of the environment and the conservation of energy and natural resources. What seems much more urgent to us today and is the main long-term future goal of the entire humanity is not related to the most astonishing technological wonders of architecture, but precisely to the environmental goals that architecture can fulfil in terms of aesthetics, but above all ethics. In today's time of Kierkegaardian existentialist anxiety and concern at all levels, the ethical and aesthetic spheres of architecture must work hand in hand. In its philosophical, ethical, aesthetic, cultural, sociological and anthropological essence, the architecture of the twenty-first century should strive to harmonise the relationships between people and their natural and social environment. Although the philanthropic and environmental demands of architecture aesthetics may sound like pure utopia due to our awareness of the power of the global political-economic goals of neoliberal capitalism, architecture in some cases retains its ethical-aesthetic autonomy and manages to resist the prevailing waves of general globalism. 


\section{GLOBALISM AND STORYTELLING ARCHITECTURE}

The global network of politically and financially powerful participants regulates the entire world market, economy, politics, resources, environmental goals, the world of media and information through state-of-the-art technology. Today's world cities are distinguished by the Western consumer culture, which is the result of cultural and economic imperialism, above all, the dominance of American influence around the world. Simulacra of power concentrated in global influencers, such as the American McDonald's or Swedish IKEA, create values, habits, standards, life style and the whole aesthetics which is implemented globally. A similar situation occurs in architecture, which adopts transcultural features under the influence of cultural globalisation. The transfer of global influences to local architectures has been increasing since the time of the Renaissance and the first geographical discoveries. By affirming the architecture of modernism throughout the twentieth century, the globalist character that architecture has retained to date was achieved. The German Bauhaus (1919-1933), the first modern architecture school whose centenary is celebrated this year, played the key role in the global acceptance of modernism. Through the integration of theory and practice, combining art and craft with modern technologies, Bauhaus revolutionised architecture, design and art. The modernist globalism of architecture accomplished its rise before the Second World War, and after the war, with the emigration of the leading modernist architects to the United States, modernity as International Style got its confirmation all over the world. ${ }^{2}$

The fundament of the aesthetic revolution of architecture realised by modernism was in innovative technologies of construction and new materials (cast and reinforced concrete, glass and steel), which led to a radical change in the shape and form of architecture. Today, with increasingly perfect performance of new materials and construction techniques, the main revolution in architecture takes place at a speculative and scientific-epistemological level, from the moment when architects replaced hand drawing with CAAD (Computer-aided architectural design). Since the 1980s, entering the era of computer technology, the designing methodology has completely changed, as well as the realisation of architecture in practice. In the past, the most vivid representations of the architectural work were made up of models and drafting axonometric drawings, and today digital 3D architectural models, in addition to being visually convincing, have a direct correlation with engineering software, which allows information from computer 3D models to be directly used in the construction and building of architecture. 
The aesthetics of architecture, in addition to its speculative-philosophical side, is largely related to the issues of technical and technological development of architecture. The general globalisation of the world, even the world architecture, evolves through technologies that carry out the diffusion of homogenised ideas. Today, in the architecture world, it is no longer about superstar architects (Zaha Hadid, Rem Koolhaas, Norman Foster, Peter Eisenman, Frank O. Gehry, Santiago Calatrava, Daniel Libeskind, Jean Nouvel, Renzo Piano, Massimiliano Fuksas, etc.) - the main transmitters of globalism are large multinational engineering and architectural companies that provide a wide range of services (architectural design, urban planning, engineering, landscape architectural design, consulting, construction, management, etc.), employ over 1,000 people, have their offices and conduct projects all over the world. ${ }^{3}$ Therefore, architecture is the leading asset in the hands of world capital. The prestige and influence of global participants in neoliberal corporate capitalism opens through the most current markets for architecture, economics and tourism concentrated in the Middle Eastern, Asian and Arab countries. ${ }^{4}$

The pure and simple "less is more" aesthetics of modernism, the philosophical and anthropological concern of postmodernism and the metaphysical game of deconstructivism, are all behind us. The architecture of the twentyfirst century has turned to the "new Baroque" in view of the many crowded forms and shapes, and in terms of celebrating the power of their global patrons. In the domain of aesthetic experience, today's architecture should cause the climax, catharsis, and initiate the general exaltation of all senses. The real example of this architecture are buildings that arise in Dubai at an enormous speed, racing in height, luxury and extravagance. ${ }^{5}$ (Figure 1) And not only in Dubai, but from the

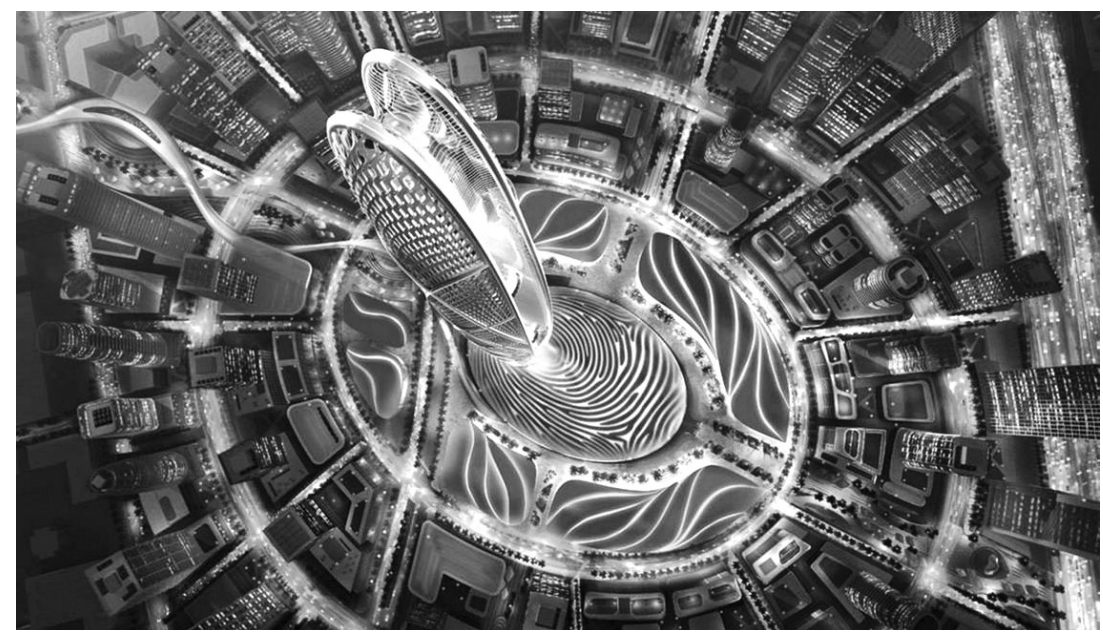

Fig. 1. Skidmore, Owings and Merrill LLP. Bujr Jumeira, Dubai. Completion expected in 2023. 
general position of today's architecture - architects turn to expression, fantasy, imaginary, the unusual and often the alogical. New technologies open up new horizons of aesthetics of architecture. In addition to globalist architecture whose aesthetics works in the service of the capitalist ideology of progress, the sphere of digital architecture provides opportunities for autonomous, independent multimedia practices that experiment with architecture and art. ${ }^{6}$ These small "intimate" architectures represent a kind of storytelling architecture - they are publicly exposed in contrast to the rules of business, marketing and politics, and their global impact is transmitted through the Internet portals and social networks.

The scope of meaning of the term storytelling architecture can relate to multiple levels of meaning. In its broadest sense, storytelling architecture relates to the general meaning of storytelling as a social and cultural activity of conveying the oral heritage of a community. As architecture is one of the reflections of the culture of a nation or community of people, the narratives that architecture transmits can move from historical, metaphorical, symbolic, educational, ethical, ideological, political, mythical, folklore, ethnological, anthropological, etc. Architecture is a visual memory transmitter, and in its archetypal domain, storytelling architecture may be understood as the precursor of writing. The constructed structures as a "recorded" oral story in the medium of architecture through their duration in time constantly achieve new emancipation through which they extend their meanings. In the broadest sense, storytelling architecture acts as a document in time and history, or might involve avant-garde aesthetic practices of experimentation in the media of architecture and art. Within the framework of architectural profession, the term storytelling architecture is most often used in connection with different ways and techniques of presenting and explaining the architectural project to the audience, clients and investors who are usually not from the world of architecture. Today there are numerous resources and media that enable the most efficient explanation of the project (sketches, diagrams, models, computer 3D renderings, films). The most effective architectural storytelling tools are certainly digital softwares, which allow architects to present the scenario of their project more convincingly in order to sell it better on the market. Storytelling architecture is one of the most important stages of the project, with architecture gaining the role of narration and expanding the field of its aesthetic action that includes a new philosophical, psychological, social-behavioral, marketing and cultural level of the narrative development of architecture through the scenario compiled by the architect and his working team. The storytelling phase of the architecture becomes a place of architecture meeting with other arts, music, theater, literature and various multimedia approaches. 


\section{ARCHITECTURE IN THE CONTEXT OF ENVIRONMENTAL AESTHETICS}

Today's beliefs about the fragility of nature and the critical consequences of human activity, primarily urbanisation and pollution of the environment which we live in, have contributed to an increasing awareness of the importance of conserving nature and its resources. Therefore, many sciences develop their research in accordance with the principles of environmentalism. One of the relatively young branches of aesthetics development is environmental aesthetics, based on the principles of sustainability and appreciation of natural, human and human-influenced environments. Environmental aesthetics explores the aesthetic positions of balancing relationships between people and their environment (both natural and human), through exploitation of resources and technological development that does not disturb the natural, sociological and economic system. Environmental aesthetics is especially developed in the area of Anglo-American aesthetics and analytical traditions. Although the main theme of environmental aesthetics is the natural environment, the importance of aesthetics of built environment, aesthetics of social environment, and the aesthetics of everyday life has increased lately.

The ideas that environmental aesthetics deals with can be traced through the history of aesthetics from the age of antiquity to the present. After the founding of aesthetics as an independent discipline in the second half of the eighteenth century, the aesthetics of nature was considered, which was a progenitor of environmental aesthetics. During the eighteenth and nineteenth centuries, Kant's concept of disinterestedness was especially developed when it comes to aesthetic appreciation of nature. However, with the focus of aesthetics on art issues in the twentieth century, aesthetics as a discipline became almost equal to the philosophy of art. After the emergence of environmental and ecology movement and the awakening of general conscience of protecting the environment, after the 1970s there was a particular interest of aestheticians and philosophers for environmental aesthetics that emphasised the importance of aesthetic considerations of nature, and shifted the focus of aesthetics from art into the domain of nature and the general environment. From the beginning of the twenty-first century, environmental aesthetics covers the study of the aesthetic significance of almost everything other than art. ${ }^{8}$ The research domain of environmental aesthetics highlights the need for restructuring the theory of aesthetics in line with the various circumstances and applications beyond the world of art. Therefore, environmental aesthetics represents one of the most important challenges of today's aesthetics. 
Architecture occupies large quantities of environment, and the unstoppable rise of urban environment at the expense of the natural environment points to the great importance that aesthetics of architecture can accomplish as one of the branches of environmental aesthetics. Modern architecture stresses the appreciation, preservation, restoration, maintenance, improvement and conservation of all environments - natural, urban and social as one of the most current conditions of its ethical, aesthetic and humanistic achievements.

Architecture is most often defined as the art of space modeling or the art of volume modeling. Architecture determines the environmental space in terms of the interior and the exterior. In contrast to the Euclidean space, a space that "closes" and "opens" with architecture is possible to perceive by one's body senses. Corporal perception of architecture in various cases may include the synthesis of visual, audio, tactile or smell sensory experiences that are involved in the construction of a specific atmosphere that a particular architectural work or set of works expresses. As receptors of the environment, space or architecture, we are limited by our corporal space which is related to our sensory and cognitive abilities. Although the environmental aesthetics in terms of its themes dissociates itself from aesthetics of art, the environmental aesthetics of architecture raises the issues related to architecture from the position of art. In addition to this, the environmental aesthetics of architecture represents an extensive field of research, since it is intertwined with social, cultural, artistic, economic, ideological, ecological factors that emphasise the most important fact of an environmental approach: neither natural nor human and humaninfluenced environments exist separately, but they are in a mutual relationship and coexist as such. This leads to a general conclusion about the impossibility of self-establishment of environmental aesthetics, since it arises and connects with various fields of research, primarily with ecology, philosophy, psychology, anthropology, cultural studies, geography, architecture, urban design, environmental design, and ultimately art. ${ }^{10}$

The article "Contemporary Aesthetics and the Neglect of Natural Beauty" written by a Scottish philosopher Ronald W. Hepburn was crucial for the development of environmental aesthetics, since it advocated the view that, within aesthetics as a philosophical discipline, the difference between aesthetic appreciation of nature and art should not lead to neglecting the study of nature in aesthetics. ${ }^{11}$ To this end, Hepburn claimed that the prevailing orientation of aesthetics to topics in the field of philosophy of art leads to a partial and incomplete consideration of the problems aesthetics as a philosophical discipline deals with. Hepburn's renewal of interest in the aesthetics of nature, 
examined through a complex interplay of emotions, imagination and thought, provided the basis for new views and foundations of environmental aesthetics, which were further elaborated by Allen Carlson, Stan Godlovich, Noel Caroll, Emily Brady, and others. Environmental aesthetician Arnold Berleant believes that the aesthetic experience begins with the perception of the environment, either natural or humanly modified, and continues to art. ${ }^{12}$ Berleant develops an idea of aesthetic engagement, and considers that environmental perception is in the quality of engagement of our senses in perception, that is, participation in environmental experience. Finnish aesthetician Yrjö Sepänmaa expands the notion of environmental aesthetics beyond nature to the field of art and contextuality. ${ }^{13}$

One of the aspects of the environmental approach to the aesthetics of architecture is biophilic architecture. Man nowadays spends most of his time indoors, and therefore feels a lack of biophilic activities. ${ }^{14}$ For that reason, man tries to connect in different ways with nature and living systems, and architecture is one of them. The lack of time spent by humankind in nature, ecosystem degradation and fast urbanisation direct the urban aesthetics of architecture to focusing on the development of smart cities, which are biophilic cities with the increase of green spaces in and around cities. ${ }^{15}$ Therefore, biourbanism focuses on the urban organism, as a hypercomplex system in which internal and external dynamics exist, as well as their mutual interconnections. The city is viewed as a system of perceptive information that we receive from the environment.

As mentioned above, apart from the visual experience, the perception of the architectural environment can include various interactive aesthetic experiences caused by smell, taste, emotions, music, sounds, light, etc. In other words, architecture is able to form a specific aesthetics of the atmosphere. German philosopher Gernot Böhme, who approaches environmental aesthetics from the point of ecocriticism, considers the relationship between culture and environment. ${ }^{16}$ Böhme establishes the notion of the aesthetics of atmosphere, through which he restores Baumgarten's founding of aesthetics as a science of sensibility. ${ }^{17}$ Böhme's aesthetics of atmosphere represents a new approach to aesthetics, in contrast to the classical aesthetics of Kant to Adorno, which was primarily the aesthetics of judgment and mainly related to the theory of the work of art. It is, on the other hand, a reference to the questions raised by aesthetics at the beginning of the eighteenth century when it was defined by Alexander Gottlieb Baumgarten. From this perspective, Böhme's aesthetics of atmosphere is above all a theory of sensory experience. It is not only aesthetics of reception, it is also related to the production of atmosphere. Böhme's term "the ecstasies of 
things" is based on the theory of atmosphere. Things are characterised by their qualities and the qualities are those that distinguish them from other things, and the term "ecstasies" refers to the way things affect the space, or how they emanate in space. ${ }^{18}$

The term atmosphere originates from metrology and signifies the pregnant upper layer of air. It is not until the eighteenth century that this term began to be used in a metaphorical meaning, primarily for states which are "in the air" in the sense of emotional space description. ${ }^{19}$ The term atmosphere today is widespread in the various contexts of physical-material, socio-cultural, psychological, historical-temporal and aesthetic determinations. In terms of architecture, the aesthetics of atmosphere in its basis implies an emotional perception of contemplative and real space, hence it is reduced to the "emotional climate" that prevails inside and outside an architectural part or urbanistic entity. The new perspective provided by the aesthetics of atmosphere in the aesthetic consideration of architecture focuses on intersubjectivity as a form of general and synergistic aesthetic communication. In this sense, the aesthetic experience provided by architecture is not only individually subjective, it also possesses a much more complex intersubjective character. This intersubjective level of aesthetic communication of the environment created by architecture reaches the unambiguous level of visual perception of architecture and enriches it with ethical, sociological, psychological and semiological values. In this regard, the important issue of contemporary aesthetics of architecture is particularly emphasised: How do the atmospheres produced by some architectural or urban space perceive and cognitively connect with contents that are not explicitly given through the physical characteristics of architecture? We may conclude that the atmosphere created by architecture causes us to feel and imagine what is impalpable, the ideas and impressions that our mind, unconsciously, intuitively and emotionally realises as a whole aesthetic experience inspired by architecture.

In Böhme's view, the atmosphere represents a typical phenomenon that is inbetween, something between subject and object. ${ }^{20}$ This intangibleness makes the atmosphere even more complicated and interesting concept for research. Creating the atmosphere by architecture implies material conditions, things, instruments, colours, ligts effects, music and sound effects, while the atmosphere itself is not a thing, it is between the object and sensory perception of subjects. Therefore, creating an atmosphere implies arranging the conditions under which the atmosphere can be achieved. Architectural work affects space on multiple levels with its formal characteristics (mass, volumes, surfaces, symmetry, asymmetry, 
rhythm, the relation between the full and the empty, style, etc.), but also through informal aspects: music, scents, sounds, movements and people's presence in the arhitectural environment. The atmosphere in architecture is created through a complex relation of the object (formal and informal characteristics of architecture) and the subject (audience, users) that makes the perception and is brought into a certain emotional state. Therefore, the atmosphere expresses the character of architecture that is recognised through various aesthetic qualities, for instance lovely, strict, elegant, melancholic, grotesque, delicate, cheerful, witty architecture. We can conclude that the aesthetics of the atmosphere in the context of architecture can become a significant building element of architecture that is not material in nature, such as stone, glass or concrete, but is created and developed in a philosophical, aesthetic, sociological, psychological, and cultural collaboration of architectural or urban creation and users.

\section{THE BEAUTY OF GROTESQUE}

One of the specific ways of creating an atmosphere by architecture is revealed by the aesthetic field of grotesque that can be recognised in contemporary architecture at different practical and theoretical levels. The grotesque acts on a specific aesthetic level, and in architecture we can mark every form of opposition to generally accepted norms and values as grotesque. The grotesque is a particularly aesthetic term and is based on the expression, structure, style and method of creating an architectural work. The term grotesque originates from the Italian word grottesco (grotta-cave), emerging at the end of the fifteenth century as a mark of the then-painted monumental animal-plant metamorphosis of the late antique Roman ornamentation that decorated the walls of the Roman Thermae. Since its creation, the grotesque signifies a caricature-fantastic or distorted, unnatural display of reality that causes feelings of horror, fear, and borders with the irony. ${ }^{21}$ The aesthetics of grotesque in contemporary architecture is most prominent in digital architecture, hyperbolic exuberance architecture of globalist landmarks, but also in avant-garde experimental architecture. The specific discourse of the grotesque in architecture is reflected through expression, surreal, alogical, hyperreal, transaesthetic, and the absurd. Grotesque architecture is dynamic, multi-significant, it plays with meaning and problematises the standards of the beautiful. It establishes the architecture of the simulacrum, which constructs the atmosphere of exaltation and exuberant excitement through the animated digital images of architecture or architectural structures in real space. In this paper we will shortly discuss three manifestations of grotesque discourse in architecture: "Dubai-style storytelling architecture", "digital architecture of exuberance" and "ephemeral architecture". 
Dubai-style storytelling architecture is based on the transaesthetic concept of architecture, whereby Dubai as a physical-geographic space and its designing architecture constitutes a separate environment-a world that is more real than the reality itself. ${ }^{22}$ It is an inverted image of the world, a picture of the technological power of architecture, a picture of prestige shaped by the economic power of capital. Dubai is a place where architecture reverses logic, and grotesque marks aesthetics. There was nothing there but a desert for decades, and today it swarms with the architectural globalist metaphors of "modernisation" and the globalisation of the Islamic world. Dubai-style storytelling architecture is a dominant expression of the contemporary architecture of extreme technological reach that is globally promoted around the world. Under this model, hotels, business buildings, traffic stations, airports, commercial centres, etc., are designed. The goal of this grotesque architecture is to be noticed, to attract as many users as possible and to cause catharsis of perceptive experience without cessation. (Figures 2, 3)

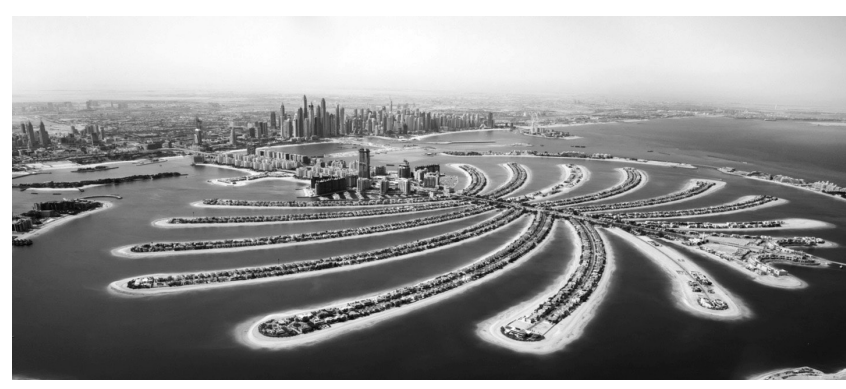

Fig. 2. Palm Jumeirah in Dubai, The world's largest artificial island in the shape of a palm tree.

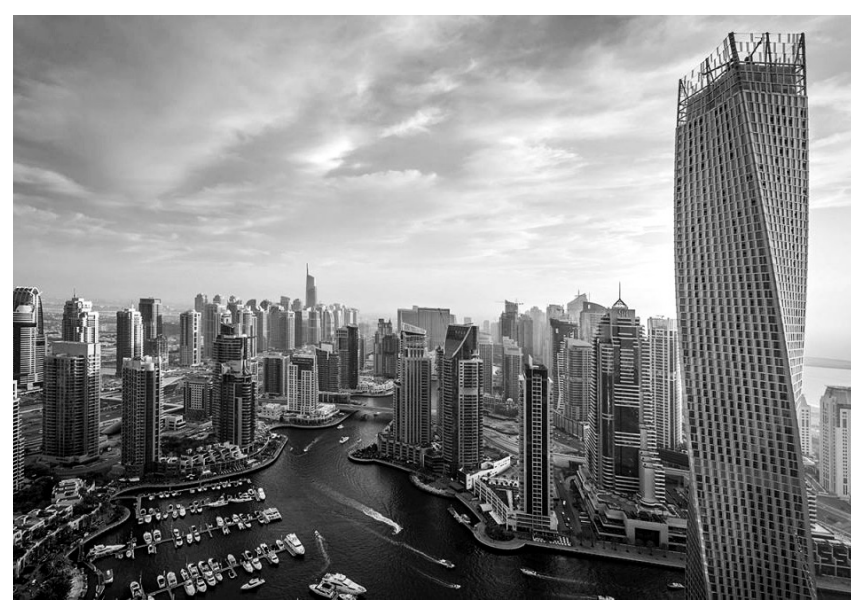

Fig. 3. Dubai tallest skyline in the world. 
The new media of architecture, computer software and modern building technology, have provided new opportunities for experiencing architecture and new possibilities of aesthetic contemplation of architecture. Through digitalisation, architecture has stepped beyond the aesthetics of form and solid space into the imaginary, hyperreal, simulacrum, and transaesthetic space. One of the most extreme examples of grotesque digital architecture of exuberance are the projects of the Argentinian architect Hernan Diaz Alonso, the founder of the Xefirotarch design studio. (Figures $4 a, 4 b, 5 a, 5 b)$ Diaz Alonso uses digital technologies to design grotesque forms of architecture that "provoke" communication with the environment. The aesthetic effects of his projects highlight the multiple possibilities of computer rendering of 3D architectural models that are reduced to the perception of architecture as image-perceived through colour, shadow, reflection, and hyperbolic forms which are associated with monstrous and xenophobic images. Geometry is eliminated, the form is split, it degrades the rigidity and volume of architectural forms, and the image expands as the essence of the aesthetic experience of Diaz Alonso's architecture. These projects nullify beauty as one of the basic concepts of aesthetics and establish a grotesque discourse in architecture by creating an atmosphere of fear, monstrosity, distortion, decay, illness and horror. By designing through animation, Diaz Alonso introduces the movement to architectural design, so the architectural creativity favours the relationship of time and space dimensions, and becomes like filming. The peak of Diaz Alonso's grotesque was reached in his project for the Museum Pavilion in Patagonia (Figure 6). Here he used the animal meat from the slaughterhouse as the main conceptual motive, and at the same time, as the building material for the Museum Pavilion. This is an extreme form of the aesthetics of ugly in architecture, but not in terms of kitsch or inadequacy in the environment, but rather in the creation of a specific atmosphere of horror, which is deviant and distorted in order to create the grotesque that shocks and causes the atmosphere of absurd. This is an exact manifestation of architectural aesthetics of the atmosphere, which in this case is created not only by architectural means, but by complex emotionalempathic means. In the 3D model of the pavilion, the observer visually, but also emotionally perceives the architecture of beef that, like a tumour, metastases, leaks, breaks through and spills through metal spherical and conical-hyperbolic forms resembling prostheses. The aesthetic point of this project is not the destruction of reality and the structure of imaginary hyperrealism, nor is it extravagant eclecticism of shape, forms and materials, but it is an attack on the very aesthetics of the form which is abandoned and disintegrated. The grotesque atmosphere of the museum project tackles the concept of the form in architecture, and brings aesthetics in touch with semiology - in the framework of the meaningful and metaphorical. 

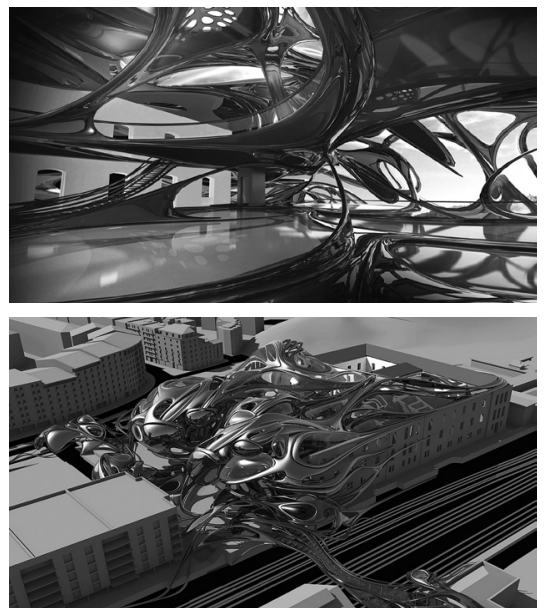

Fig. Hernan Diaz Alonso and Xefirotarch. 4a,4b. Tabakalera, Competition project, Spain 2008.
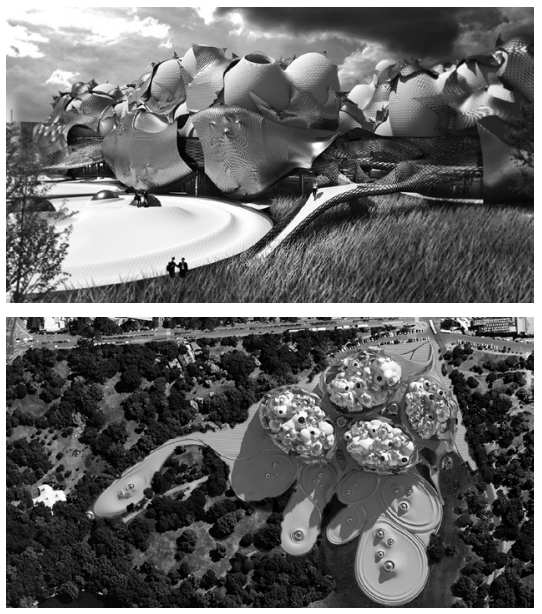

Fig. Hernan Diaz Alonso and Xefirotarch. 5a,5b. Project of New National Gallery and Ludwig Museum, Budapest, 2015.

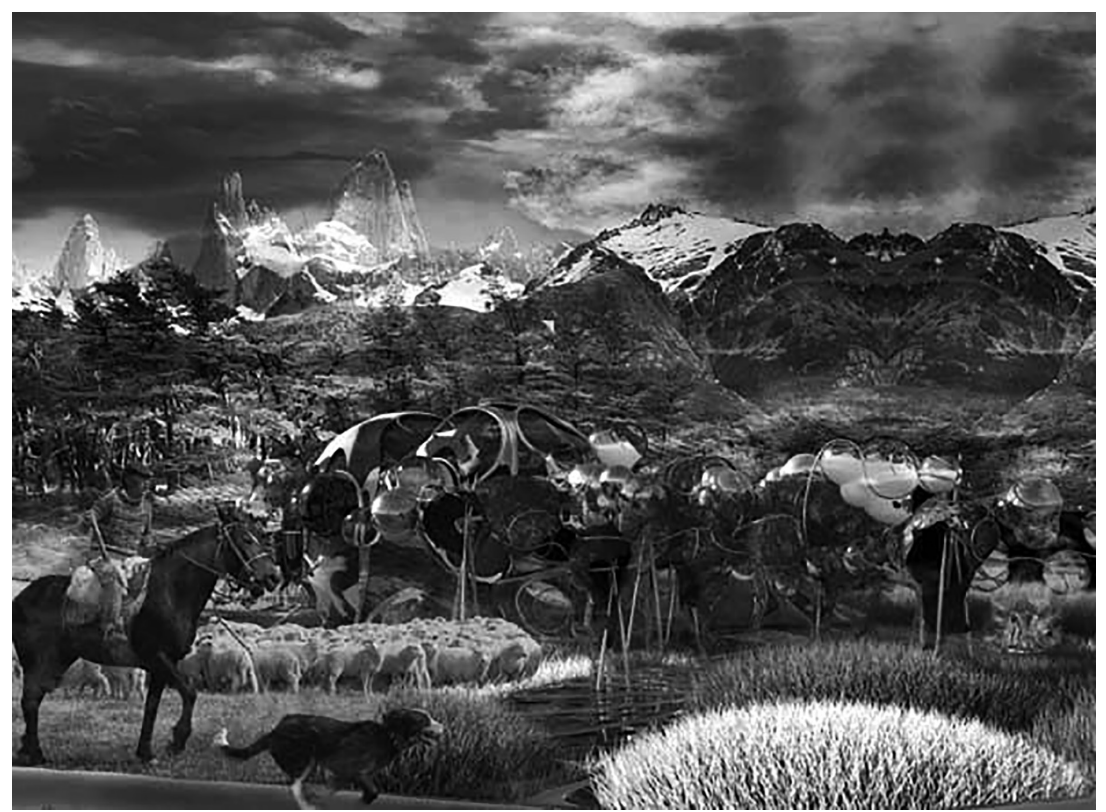

Fig. 6. Hernan Diaz Alonso and Xefirotarch. Project of Pavilion in Patagonia, 2012. 
The architecture of grotesque works on the inner, often implicit level. In the works of Marc Fornes, Volkan Alkanoglu, Ronald Snooks and Robert StuartSmith, the digital architecture of exuberance conducts the abolition of solid, rigid materials that had served the architecture for centuries, such as stone, wood, bricks, blocks, concrete masses, metals, and glass. The increasingly perfect performance of new materials, such as super-thin aluminium, various types of biorubber and bioplastics makes it possible to transfer the aesthetic impression from 3D computer models to the realisation of architecture in practice. The materials are becoming increasingly soft and flexible, and the grotesque aesthetics is based on the physical and materialisation properties of the material itself, and not only on the shaped and formal level. These new materials undo the division between the exterior and the interior of architecture, since the inverted appear in both cases the same (both inside and outside). Contemporary architectural projects are becoming more and more curved thanks to computer software that allow the implementation of complex curves in construction. Softwares and computer tools have affected changes in the aesthetics and production of the global design work in general. Today it is possible to model millions of surfaces through computer models at the same time, which was previously not possible due to the limited possibilities of computer software and hardware.

Digital architecture of exuberance accentuates the hyperbolisation of closed volumes of architecture, denying details such as windows, doors, structural division to floors, etc. This tendency of architecture towards favouring the mass in a certain way performs depersonalisation of architecture through a grotesque emphasis on the interplay of large-scale volumes.

One of the best examples of the avant-garde spirit of architecture expressed through the grotesque is the work of the French architect Francois Roche, the founder of the polymorphous architectural organization New-Territories. Roche and New-Territories expand the boundaries of their work outside of architecture, and realise multidisciplinary, theoretical, movie and robotic laboratories, architectural experiments, psycho-architectural case studies, bioarchitectural constructs, etc. In a broad programme of his accomplishments, Roche and his group implicate strategies of disobedience through the grotesque aesthetics of contempt for populist elements of culture. In this case, the grotesque in architecture operates on implicit and explicit aesthetic levels. Explicitly by means of direct expression in the forms, installations, actions in the space, film scenarios, etc., and implicitly including the influences generated by New-Territories synesthetic works: manifestos, theoretical texts, ephemeral installations, architecture related to ecosophy, biology, technology, robotics and human psychopathologies. (Figures 7, 8, 9) 


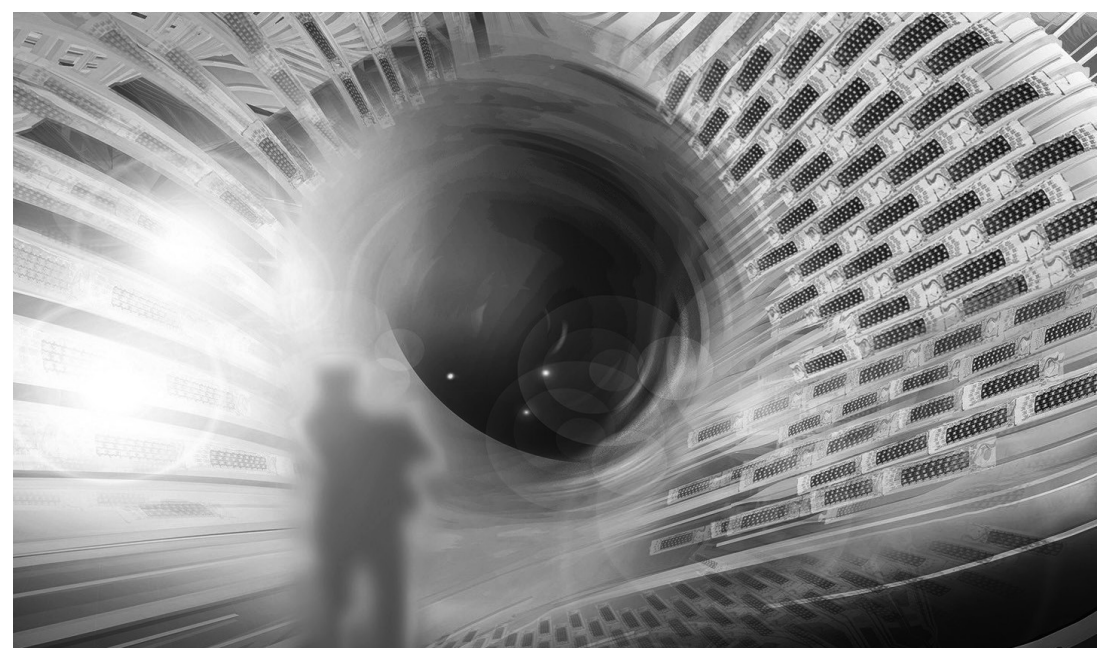

Fig . 7. Francois Roche and New-Territories. The Building Which Never Dies, France-Austria, 2009-10.

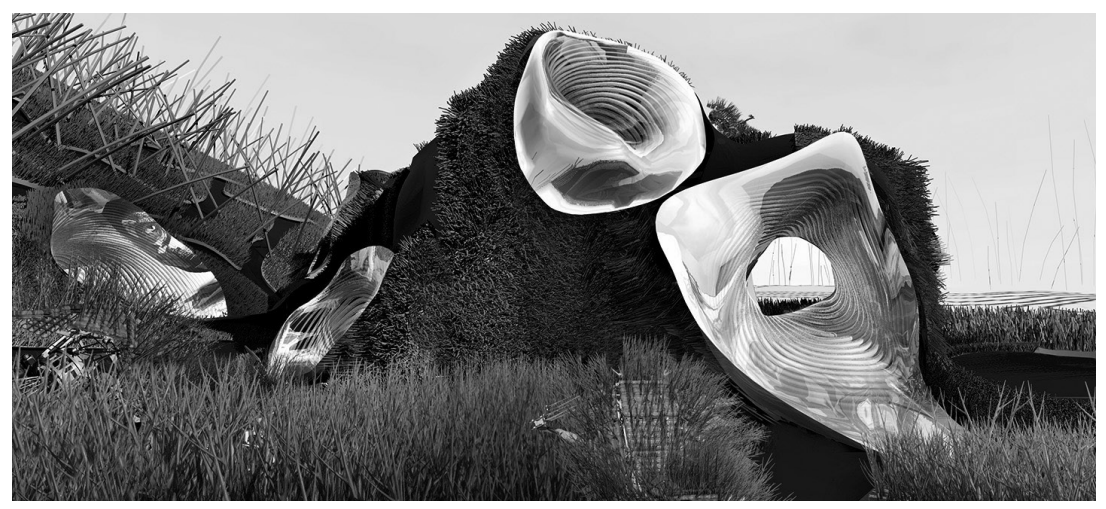

Fig. 8. Francois Roche and New-Territories. He shot me down, Korea, 2006-07.

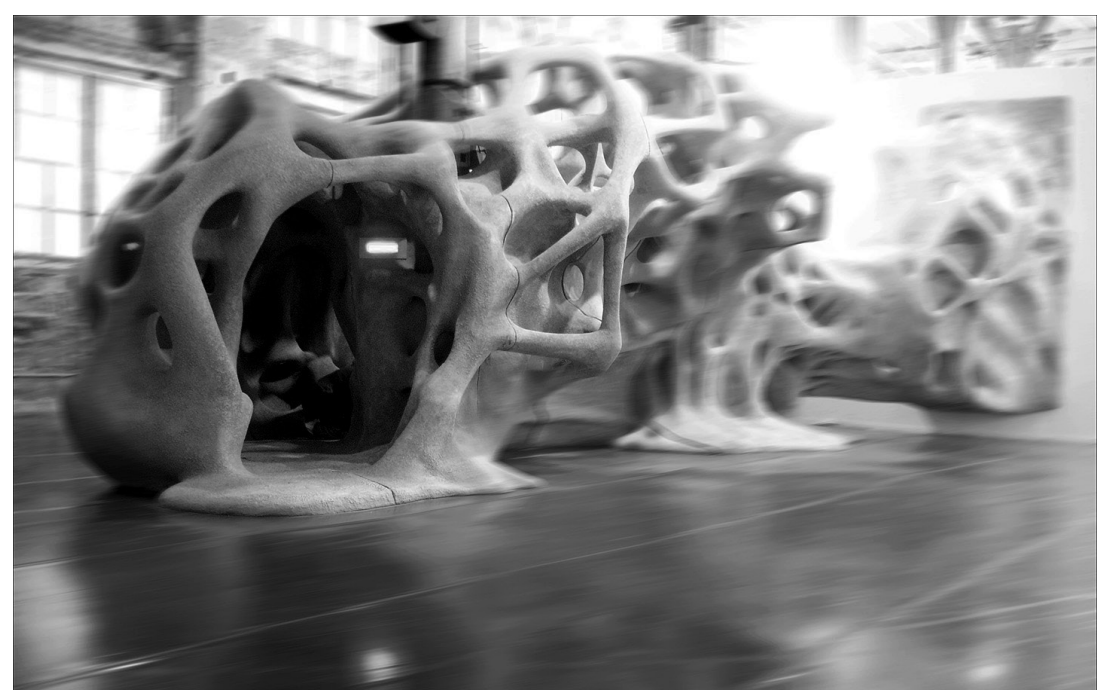

Fig. 9. Francois Roche, New-Territories and MAM/ARC. I've heard about, Paris, 2005. 
As we had the opportunity to see in the previous examples, the source of the grotesque in architecture is often in the aesthetics of fright and horror. However, there is also an optimistic side of the grotesque in architecture that finds its source in the culture of humour, wit and inventiveness, and is related to the forms of small-scale architecture, prefabricated and temporary installations of the so-called "ephemeral architecture". Ephemeral architectural structures express a kind of storytelling architecture that has the role of bearer of meaning and narration. This type of architecture includes various short-lived structures, temporal exhibitions, pavilions, architectural-sculptural installations, experimental architectural designs, etc. Storytelling ephemeral architecture usually promotes cultural content (traveling theaters, cinemas, exhibitions, pavilions designed to promote local culture, folklore and tradition), new architectural materials and technologies, and the frequent grotesque role of this architecture is to intrigue and test the social environment and record aesthetic experiences of people. ${ }^{23}$ Although every aspect of revolutionary potential in society, art and culture is lost before the economic goals of global politics, architecture manages to defend its creative social and political freedom in these positively grotesque forms of ephemeral architecture. (Figure 10)

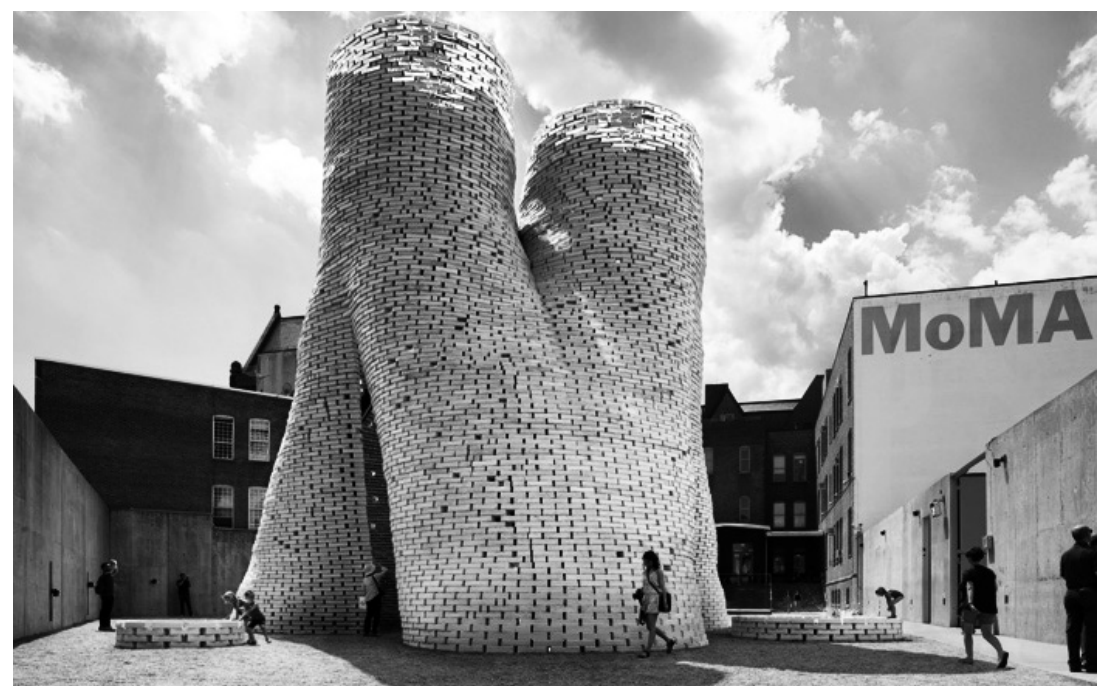

Fig. 10. "The Living" (New York-based designed practice group), 12m-high Circular Tower made of biodegradable bricks for MoMA PS1's annual Young Architects Program, 2014. 


\section{CONCLUSION}

Modern architecture in its aesthetic domain resists Nietzsche's nihilism, which is still present in the twenty-first century in the crisis of philosophy, aesthetics, art, and human society in general. Long-term predictions such as those of Marshall McLuhan about the importance of the role of the media in terms of decentralisation and global distribution of information have fulfilled at all levels of human action. The global merging of the intimate and public sphere of society has had a great influence on aesthetics and its subject matter of research. As a result of globalism, transculturalism and "inter(all) disciplinarity" as a general approach of modern times, the basic difficulties of today's aesthetics have emerged: the boundaries of aesthetics have become very loose, permeable and sometimes invisible. Digital media and social networks represent aesthetic, artistic and cultural scenes in which amateurism coexists with relevant scientific contributions. Baudrillard had already indicated the transaesthetic character of our world and its movements towards general aesthetisation, commercialisation and transformation of everything, and even architecture itself turning into consumable goods. Although the reality is often masked by globalist goals, and the original reality no longer exists after its transaesthetisation, architecture understood as a simulacrum opens an unlimited scope of new possibilities for aesthetic research, interpretation and practice of performing architecture as a social, cultural, technical and artistic discipline. Contrary to Baudrillard's pessimistic view of culture and art of the twenty-first century, transaesthetics in the domain of architecture can be interpreted, above all, from an optimistic standpoint. Parametric and digital design in architecture is able to produce a hyperreal reality based on freedom and creation that the architects had never known before. Therefore, the architecture with the qualities of transcultural and transaesthetic succeeds in overcoming the unilateral global goals of neoliberal capitalism with the power of its creations, providing the maximum of creative charge.

We have seen from the previous examples of this study that the digital architecture of exuberance of Diaz Alonso or the experimental architecture of Roche and the New Territories group represent two extremely creative ways of using modern technologies for the purpose of aesthetically, ethically and politically free architectural and artistic expression. The orientation of architecture to the digital methodology of work has highlighted a new positivist belief in the richness of transaesthetic experiences given through architecture. Computer design and modern technological practices of architecture confirm the benefits of transaesthetic architecture which is realised in the philosophical interface between utopia and reality. Through animation, virtual perception, 
digital simulation, direct transformation, modification, and interactive perception of architecture, digital architectural information is established as the basic equivalent of aesthetic value. At the same time, digital architectural information is a technical-engineering value based on which the realisation of architecture is carried out in practice. Therefore, depending on the point of view, digital architectural information determines the aesthetic extension of architecture - which can be regarded as hyperrealism, which is neither a lie nor truth, since it exists as architecture in the domain of the transaesthetic. ${ }^{25}$ On the other hand, digital architectural information is a simulacrum that has practical potential and is transferred from the domain of the hyperreal to the domain of real and existential when it comes to the realisation of computer models of architecture in the built objects. As the technical possibilities of concrete, glass and metal structures were examined with fascination in the twentieth century, today, in the second decade of the twenty-first century, digital media have completely transformed the way of thinking and the very philosophy of architecture. Digital architectural information also works in the field of social cohesion, which best reflects the concepts of intelligent architecture, smart cities and environmental aesthetics of architecture. Technology should not be understood as an antagonist and destroyer of nature and the natural environment. New technologies are precisely the basis for a more human and ethical approach to modern architecture that seek to reconcile economic goals with the general development of society, bearing in mind ecological and environmental goals. Therefore, the highest goal of architecture aesthetics should be phronesis, which is reflected in a combination of practical and thoughtful work in architecture. This is why environmental aesthetics of architecture revitalises issues that were forgotten and strives to rethink the general values of true, good and beautiful which have constituted the basis of humanism and individual and collective responsibility from antiquity to this day. 

(Split: Verbum, 2000).

International Style was the name of the exhibition organised by architects Henry-Russell Hitchcock and Philip Johnson in 1932 at the New York MOMA Museum, assuming under this name a modern style in architecture that had been developing since the 1920s in Germany, France, the Netherlands and other European countries. Shortly before the Second World War, Mies van der Rohe, Walter Gropius and Marcel Breuer emigrated to America, Hannes Meyer to the USSR, and then to Mexico. The principles of Bauhaus and Le Corbusier's modernism after the war in the fever of the great construction of new life through the new architecture started to gain their worldwide affirmation.

We will mention some of the largest architectural companies operating on the global architecture market: AECOM (USA), Gensler (USA), IBI Group Inc. (Canada), Nikken Sekkei Ltd (Japan), Aedas (UK), Perkins and Will (USA), DP Architects (Singapore), HOK (USA), Samoo Architects and Engineers (South Korea), Foster and Partners (UK), etc.

See examples of projects carried out by WKK architects in Bahrain, Islamabad, Jakarta, Tehran, Bangkok, Cyprus, Tripoli, and Dubai. 
Dubai is the destination of wonders in architecture: by 2023 it will have another miracle, a splitvolume skyscraper Bujr Jumeira, with oval base shaped in the form of fingerprint of the emirates's ruler Mohammed bin Rashid Al Maktoum (See: Figure 1). Dubai is the host of EXPO 2020. This will be the first time for World Universal Exposition to take place in the region of Middle East, Africa and South Asia region.

See below in this paper the work of the New Territories group, pp. 455 .

Aesthetics of everyday life involves common human objects, environments and activities, for example: artifacts of daily use, chores around the house, everyday activities, such as eating, walking, bathing, meeting people, sport, etc. See: Yuriko Saito, Everyday Aesthetics (Oxford: Oxford University Press, 2010).

Allen Carlson, "Environmental Aesthetics," in The Stanford Encyclopedia of Philosophy, ed. Edward N. Zalta (Stanford: Metaphysics Research Lab, Stanford University, 2016), accessed December 17, 2018, https://plato.stanford.edu/archives/sum2016/entries/environmental-aesthetics.

Arnold Berleant, "Environmental Aesthetics", in The Encyclopedia of Aesthetics, ed. Michael Kelly (Oxford: Oxford University Press, 1998), p.10.

Although they share similar ideas, environmentalism should not be confused with ecology. Ecology refers to a set of relationships that connect an organism with its environment or ecosystem. Environmentalism is a very comprehensive philosophical, sociological and ideological view of the world that advocates the protection and improvement of environmental health: that of people, animals, plants and non-living matters.

Ronald W. Hepburn, "Contemporary Aesthetics and the Neglect of Natural Beauty," in British Analytical Philosophy, ed. Bernard Williams and Alan Montefiore (London: Routledge and Kegan Paul, 1966), 285-310.

See: Arnold Berleant, The Aesthetics of Environment (Philadelphia: Temple University Press, 1992); Arnold Berleant, Aesthetics and Environment: Variations on a Theme (England/USA: Ashgate Publishing, 2005); Allen Carlson and Arnold Berleant, The Aesthetics of Natural Environments (Peterborough: Broadview Press, 2004); Arnold Berleant, "The Art in Knowing a Landscape," Diogenes 59 (2013): 52-62.

Yrjö Sepänmaa, The Beauty of Environments a Geeral Model for Environmental Aesthetics (Helsinki: Soumalainen Tiedeakatemia, 1986).

Biophilia means "love of life" or "love of living systems". See: Erich Fromm, The Heart of Man (Evanston and London: Harper and Row Publishers, 1964); Edward O. Wilson, Biophilia (Cambridge: Harward University Press, 1984).

In architecture, biophilic design implies a sustainable design approach whose primary goal is to restore the connection between people and their natural environment - plants, animals, and the elements of natural landscape. See: Antonio Caperna and Stefano Serafini, "Biourbanism as New Epistemological Perspective Between Science, Design and Nature," in Architecture and Sustainability: Critical Perspectives for Integrated Design, eds. Khan Z. Ahmed and Allacker Karen (Brussels, Ghent: KU Leuven Faculty of Architecture Campus Sint-Lucas, 2015), 263-269.

See: Gernot Böhme, The Aesthetics of Atmospheres (Abingdon: Routledge Publishing, 2018), 1128.

See: Alexander Gottlieb Baumgarten, Aesthetica (Traiecti cis Viadrum: Impens. Ioannis Christiani Kleyb, Vol.1: 1750, Vol 2: 1758); Aleksander Gotlib Baumgarten, Filozofske meditacije o nekim aspektima pesničkog dela (Beograd: BIGZ, 1985).

In his studies, Böhme examines the values of the atmosphere that dominates in various aesthetic contexts, such as: city atmosphere, music atmosphere, atmosphere of light, atmosphere of dusk, atmosphere in architecture, atmosphere of human communications, atmosphere of living bodies in space, etc. See: Gernot Böhme, Atmospheric Architectures: The Aesthetics of Felt Spaces (London, etc.: Bloomsbury Academic, 2017). 
Herman Schmitz considers the atmosphere to be an emotional power. See: Herman Schmitz, "The New Phenomenology," in Phenomenology World-Wide, Vol. 80, ed. Anna-Teresa Tymieniecka (Dordrecht: Springer, 2002), 491-493; Herman Schmitz, "Eutseelung der Gefühele" - english edition by Rudolf Owen Mülan and Jan Slaby "Emotions outside the box - the new phenomenology of feelings and corporeality" (Springer online editions, 8 February, 2011), accessed October 28, 2018, https://core.ac.uk/download/pdf/81787676.pdf.

Gernot Böhme, Atmospheric Architectures: The Aesthetics of Felt Spaces (London, etc.: Bloomsbury Academic, 2017), 174.

The term grotesque is used in the sense of miraculous, unusual, excessive, extreme, distorted, outcast, ridiculous, frustrated, unnatural, ironic. (See: Volfgang Kajzer [Wolfgang Kayser], Groteskno u slikarstvu i pesništvu (Novi Sad: Svetovi, 2004).

About the concept of simulacrum see: Žan Bodrijar [Jean Baudrillard], Simulakrumi i simulacija (Novi Sad: Svetovi, 1981), 10.

Ephemeral or temporal architecture constitutes a catalyst for social behaviour, refreshes space and psychologically affects passers-by. Ephemeral architecture is usually the product of interdisciplinary work of experts from various disciplines: architects, stakeholders, historians, urban planners, sociologists, psychologists, communication and media experts, etc.

See: Žan Bodrijar [Jean Boaudrillard], Prozornost zla: Ogled o krajnosnim fenomenima (Novi Sad: Svetovi, 1994), 14-19.

See the example of the Patagonian Museum designed by Hernan Diaz Alonso, (Figure 6). 
Baumgarten, Alexander Gottlieb. Aesthetica. Traiecti cis Viadrum: Impens. Ioannis Christiani Kleyb, Vol.1: 1750, Vol 2: 1758.

Baumgarten, Alexander Gottlieb. Filozofske meditacije o nekim aspektima pesničkog dela. Beograd: BIGZ, 1985.

Berleant, Arnold. The Aesthetics of Environment. Philadelphia: Temple University Press, 1992.

Berleant, Arnold. "Environmental Aesthetics." In The Encyclopedia of Aesthetics, edited by Michael Kelly. Oxford: Oxford University Press, 1998.

Berleant, Arnold. Aesthetics and Environment: Variations on a Theme. England/USA: Ashgate Publishing, 2005.

Berleant, Arnold. "The Art in Knowing a Landscape.” Diogenes 59 (2013): 52-62.

Bodrijar, Žan. Simulakrumi i simulacija. Novi Sad: Svetovi, 1981.

Bodrijar, Žan. Prozornost zla: Ogled o krajnosnim fenomenima. Novi Sad: Svetovi, 1994.

Böhme, Gernot. Atmospheric Architectures: The Aesthetics of Felt Spaces. London, etc.: Bloomsbury Academic, 2017.

Böhme, Gernot. The Aesthetics of Atmospheres. Abingdon: Routledge Publishing, 2018.

Caperna, Antonio, and Serafini, Stefano. "Biourbanism as New Epistemological Perspective Between Science, Design and Nature.” In Architecture and Sustainability: Critical Perspectives for Integrated Design, edited by Khan Z. Ahmed and Allacker Karen, 263-269. Brussels, Ghent: KU Leuven Faculty of Architecture Campus Sint-Lucas, 2015.

Carlson, Allen, and Berleant, Arnold. The Aesthetics of Natural Environments. Peterborough: Broadview Press, 2004.

Carlson, Allen. "Environmental Aesthetics". In The Stanford Encyclopedia of Philosophy, edited by Edward N. Zalta. Stanford: Metaphysics Research Lab, Stanford University, 2016. Accessed December 17, 2018, https://plato.stanford.edu/archives/sum2016/entries/environmental-aesth etics.

Fromm, Erich. The Heart of Man. Evanston and London: Harper and Row Publishers, 1964.

Hepburn, Ronald W. "Contemporary Aesthetics and the Neglect of Natural Beauty." In British Analytical Philosophy, edited by Bernard Williams and Alan Montefiore, 285-310. London: Routledge and Kegan Paul, 1966.

Kajzer, Volfgang. Groteskno u slikarstvu i pesništvu. Novi Sad: Svetovi, 2004.

Kierkegaard, Søren. Ili-ili. Sarajevo: Veselin Masleša, 1979.

Kierkegaard, Søren. Strah i drhtanje. Split: Verbum, 2000.

Saito, Yuriko. Everyday Aesthetics. Oxford: Oxford University Press, 2010.

Schmitz, Herman. “The New Phenomenology.” In Phenomenology World-Wide, Vol. 80, edited by Anna-Teresa Tymieniecka, 491-493. Dordrecht: Springer, 2002.

Schmitz, Herman. "Eutseelung der Gefühele." In english edition Emotions outside the box - the new phenomenology of feelings and corporeality, edited by Rudolf Owen Mülan and Jan Slaby. Springer online editions, 8 February, 2011. Accessed October 28, 2018. https://core.ac.uk/ download/pdf/81787676.pdf.

Sepänmaa, Yrjö. The Beauty of Environments a Geeral Model for Environmental Aesthetics. Helsinki: Soumalainen Tiedeakatemia, 1986.

Wilson, Edward O. Biophilia. Cambridge: Harward University Press, 1984. 
STUDIJA BIOLOŠKOG KONCEPTA U ARHITEKTONSKOJ MISLI: POREĐENJE „DER RAUM ALS MEMBRAN" (1926) I „METABOLIZMA" (1960)

\section{Shiho Hasegawa}

Ova studija analizira biološki uticaj na arhitekturu u 20. veku fokusirajući se na dve posebne biološke arhitektonske misli; ,Der Raum als Membran (Prostor kao membrana)“Zigfrida Ebelinga (Siegfried Ebeling) iz 1926. godine i „Metabolizam“ grupe japanskih arhitekata iz 1960. godine.

Prvo se razmatra „Der Raum als Membran“. Ebeling je arhitekturu ili prostor video kao biološku membranu, poput kože ili ćelije i izneo je teoriju biološke arhitekture. On nije samo u urbano planiranje uveo ovu biološku metaforu sa fleksibilnošću membrane, već je ugradio i biološki koncept poput Umwelt-a. Nakon toga istražuje se manifest pod nazivom „Metabolizam“, koji je 1960. pripremila grupa japanskih arhitekata. Oni su mislili da zgrade i urbani dizajni postoje protkani egzistencijom i metabolizmom, što je osnovna funkcija živih bića, i predložili su promenljive i raznolike arhitekture sa dinamičnim vremenskim rasponima.

Upoređujući ove biološke arhitektonske koncepte, ističem tri glavne sličnosti: 1) širenje biološkog koncepta ka arhitekturi; 2) ćelija kao metafora; i 3) dinamične zgrade ili urbani dizajn. Iako su autori imali različite biografije, svi su u svoje vreme uveli nove arhitektonske ideje.

KLJUČNE REČI: ARHITEKTONSKA MISAO, BIOCENTRIZAM, BIOLOŠKA ARHITEKTURA, BIO DIZAJN, MEMBRANA, METABOLIZAM, UMVELT (OKOLINA)

\section{OD BIG MEK I IKEA DRUŠTVA DO ESTETIKE ŽIVOTNE SREDINE,} PAMETNIH GRADOVA I STORYTELLING ARHITEKTURE

\section{Irena Kuletin Ćulafić}

Danas živimo u globalnom društvu koje se suočava sa različitim izazovima dvadeset prvog veka. Naši gradovi se nalaze u procesu neprestanih transformacija uzrokovanih uticajima urbanizacije, globalizacije, naprednih tehnologija, ekoloških promena i promena u domenu životne sredine, društvenih, političkih i ekonomskih kriza. Dok korporativni kapitalizam cveta, svetska populacija raste i naši gradovi se šire, arhitektura dostiže gotovo utopijske vizije, a granice estetike postaju sve propusnije i labavije. Danas naše savremeno društvo živi i deluje estetski. Počevši od umetnosti, arhitekture, muzike, religije, politike, komunikacija, tehnoloških gedžeta, naših domova, vrtova, odeće, kulinarstva, pa do sporta i life coaching-a, sve može biti predmet estetskog razmatranja.

Estetsko promišljanje arhitekture i urbanizma u svetu koji se stalno menja zahteva kritičke i interaktivne pristupe, koji neće podrazumevati samo teorijska, već i praktična estetska delovanja. Shodno tome, ovaj rad nastoji da razmotri estetske probleme savremene arhitekture i urbanizma sa globalne, ekološke, tehnološke i sociološke tačke gledišta. Priroda se danas više ne doživljava kao paradigmatski objekt estetskog iskustva, već kao naše jedinstveno kolektivno okruženje od kojeg mi kao ljudi direktno zavisimo. Iz tih razloga arhitektura nastoji da objedini etička i estetska gledišta u cilju ponovnog preispitivanja tereta koji nose naši gradovi i sagledavanja mogućnosti njihovog budućeg razvoja.

KLJUČNE REČI: ESTETIKA ŽIVOTNE SREDINE, STORYTELLING ARHITEKTURA, GLOBALIZAM, ODRŽIVOST, PAMETNI URBANIZAM I PAMETNA ARHITEKTURA, LEPOTA GROTESKNOG 